\title{
Phenotypic variability of bacterial cell cycle: mathematical model
}

\author{
Likhoshvai V.A. ${ }^{1,2}$, Khlebodarova T.M. ${ }^{1}$ \\ ${ }^{1}$ Institute of Cytology and Genetics, Siberian Branch, Russian Academy of Sciences, \\ Novosibirsk, 630090 Russia \\ ${ }^{2}$ Novosibirsk State University, Novosibirsk, 630090 Russia
}

\begin{abstract}
Annotation. Modeling results demonstrating mechanisms of different cell phenotypes appearance in a genetically homogenous population using the bacterial cell cycle model are presented. It was demonstrated that phenotypic variability represents an internal, immanent property of bacteria. The basis of this phenomenon is universal non-linear properties of the conjugated transcriptiontranslation system that controls all cellular processes. Phenotypic variability occurs in a simple, deterministic, self-reproducing system under the uniform transmission of the structural components to the daughter cells during division and in the absence of any special control mechanisms of molecular-genetic processes and enzymatic reactions.
\end{abstract}

Key words: bacteria, cell cycle, modelling, phenotypic variability.

\section{INTRODUCTION}

Mechanisms underlying the appearance of cells with different phenotypes in a genetically homogeneous population have been widely discussed in modern scientific literature. Hence, phenotypic heterogeneity based on the bistability phenomenon (when a system has two stable equilibrium states), which has been demonstrated for systems regulated by feedback mechanisms [1-7], was investigated.

A number of studies have demonstrated the influence of switching between active and inactive states of gene(s), as a result of stochastic interactions between regulatory factors and promoters of target genes [8-14], as well as DNA methylation in the transcription factor binding sites (see review [15]) on the formation, at the population level, of a bimodal distribution of cells according to the level of gene expression.

Phenotypic heterogeneity in genetically homogenous cell population due to nutrient restriction or change, or due to cellular senescence, has been demonstrated [16-19].

In this paper, we analyze cell cycle of a generalized bacterial cell using deterministic model and demonstrate that, for certain parameter values, cell cycle can be carried out in at least two different ways. It follows from the analysis that wide variety of cell cycle phenotypes represents a consequence of general principles of genetic information storage and transmission and does not require any special control mechanisms for molecular genetic processes and enzymatic reactions, as well as asymmetric cell division, that is, represents an intrinsic property of a bacterial cell. 
We assume that this property of bacterial cell can underlie bacterial persistence - a phenotypic state of uninheritable transient antibiotic tolerance observed in many species of modern bacteria [20, 21], which has been recently associated with the molecular genetic peculiarities of stress response systems, including toxin-antitoxin system [22-24].

\section{MODEL OF THE BACTERIAL CELL CYCLE}

To study mechanisms underlying the appearance of different phenotypes in a genetically homogeneous population of cells, we used a previously developed mathematical model of prokaryotic cell cycle $[25,26]$, which represents a general description of growth and division of a rod-shaped bacterial cell, initiation, elongation and termination of DNA replication, transcription of genes, mRNA translation and degradation of mRNA and proteins.

Let us assume that the cell represents a cylinder bounded by an outer shell. During a single cell cycle, the cell elongates along the central axis, while the radius of the cell remains unchanged. At the moment of division, a constriction is formed in the center, dividing the parent cell into two daughter cells. We consider five conventional genes in the model: $g P, g R$, $g C, g M$ and $g D$. The $g P$ gene encodes a subunit of the transcription factor, which assures initiation of $g P, g C, g R, g M$ and $g D$ mRNA synthesis. The $g C$ gene encodes a subunit of the translation factor, which promotes initiation of protein synthesis. The $g R$ gene encodes a structural protein of the shell. The $g M$ gene represents a set of genes that are expressed during the cell cycle, and the $g D$ gene encodes a generalized protein and RNA degradation factor.

The number of genes in each species we denote by $G_{X}, X=P, R, C, M, D$. Let $P$ denote the number of free subunits of transcription factor in the cell cytoplasm, $R$ - the number of shell protein molecules in the cytoplasm, $C$ - the number of free subunits of the translation factor, $V$ - the cell volume, $S$ - the surface area of the shell.

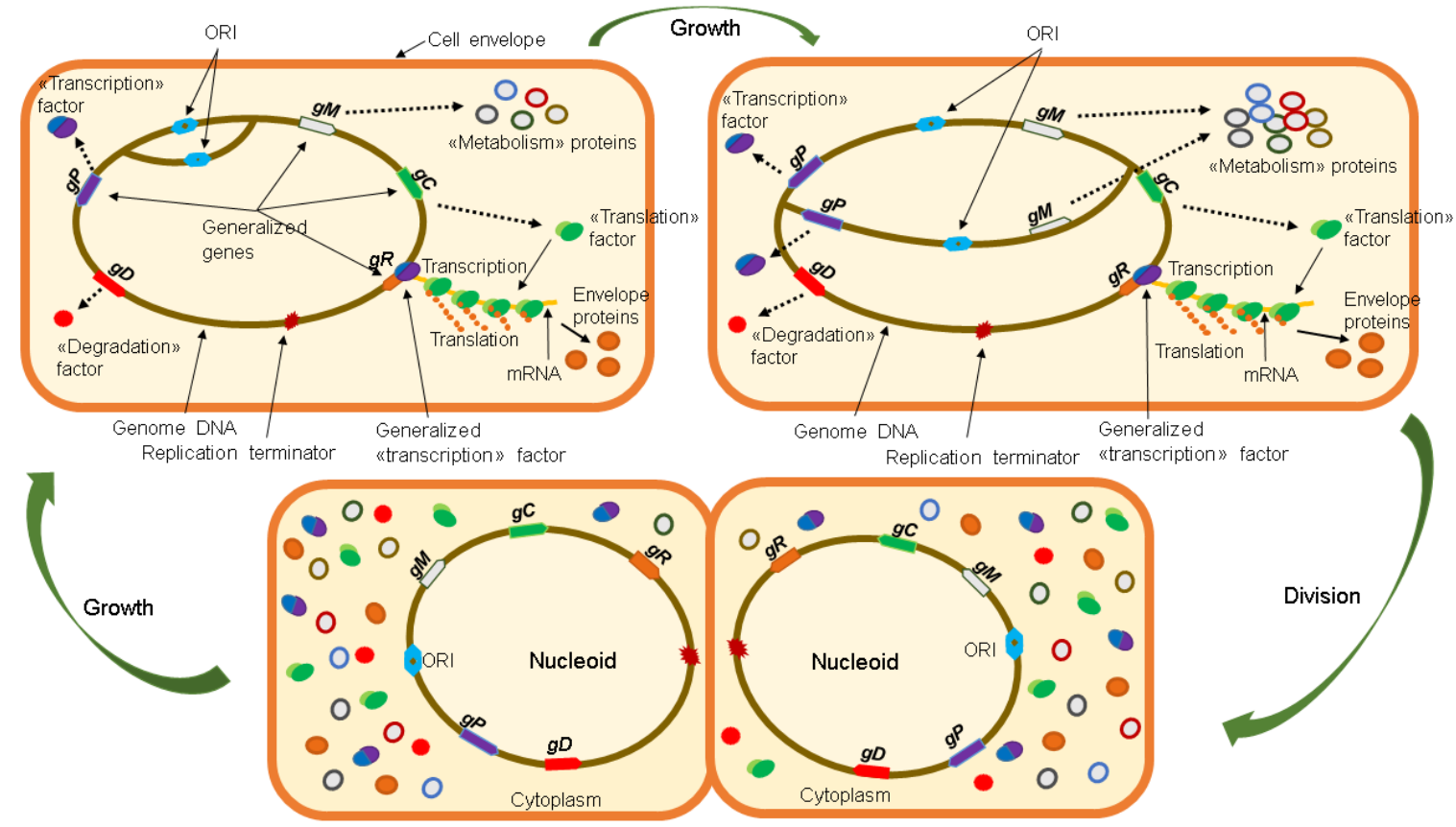

Fig. 1. Simplified scheme of the model of bacterial cell cycle. Locations of conventional genes encoding the transcription $(g P)$, translation $(g C)$ and degradation factors $(g D)$, proteins of the cell membrane $(g R)$, a set of genes that support cell functioning during its growth and division $(g M)$, and location of sites of replication initiation and termination, are illustrated. Change in the copy number of genes during DNA replication, depending on the distance of these genes from the replication start site, is shown; as well as the process of conjugated DNA transcription and mRNA translation on the example of the conventional cell membrane gene $(g R)$. According to the model, division is symmetric with a uniform distribution of cellular structures between daughter cells. Dotted arrows indicate that the process is indirect. 
Figure 1 illustrates the simplest scheme of cell growth and division described in the model, which, at different stages of the cell cycle, demonstrates DNA replication and transcription of $g P, g R, g C, g M$ and $g D$ genes conjugated to mRNA translation; as well as symmetric cell division with a uniform distribution of cellular structures between daughter cells.

We now introduce subsystems of the model of bacterial cell cycle.

\subsection{Subsystems of the cell cycle model for bacteria}

Subsystem (1) - multimerization of factors. Let us assume that multimers represent active forms of transcription and translation factors. We describe their formation by multimolecular reactions:

$$
\left[n_{1, X}\right] x^{n_{X}} \underset{k_{W X}}{\stackrel{k_{X W}}{\rightleftarrows}} w_{X}, \quad X=P, C .
$$

Where, $w_{X}$ - concentration of active forms of factors, $k_{X W}$ and $k_{W X}$ - rate constants for direct and reverse reactions, $n_{X}$ and $n_{1, X}-$ stoichiometric coefficients: $n_{X}$ determines the number of molecules in a multimer, $n_{1, X}-$ the number of molecules $X$ in the multimer active form. Since in general case active forms of factors can include different types of molecules, we assume that $n_{X} \geq n_{1, X}$ and the equality of these parameters may not be observed.

To calculate local rates of reactions (1), we consider a system of differential equations

$$
\left\{\begin{array}{l}
\frac{d W_{X}}{d t}=\underbrace{k_{X W}\left(X\left(\frac{X}{V \cdot K_{D, W X}}\right)^{n_{X}-1}-W_{X}\right)}_{v_{W_{X}}}, \\
\frac{d X}{d t}=-n_{X, 1} v_{W_{X}}, K_{D, W X}=\sqrt[n_{X}-1]{k_{X W} / k_{W X}} .
\end{array}\right.
$$

In which $W_{X}$ is the absolute number of active complexes of factor $X$.

Subsystem (2) - mRNA synthesis. We take into consideration that initiation of mRNA synthesis takes place in the regulatory regions (promoters) of the corresponding genes. As a result of initiation, elongation complex is formed, which, after a while, generates one mRNA molecule. The following equations were used to describe mRNA synthesis:

$$
\left\{\begin{array}{l}
\frac{d X_{m, b u f}}{d t}=v_{\text {ini,sinm }, X}-v_{\text {sinm }, X}, \quad X=P, R, C, D, M, \\
\frac{d X_{m R N A}}{d t}=v_{\text {sinm }, X}, \quad X=P, R, C, D, M, \\
\frac{d W_{P}}{d t}=-\sum_{X=P, R, C, D, M}\left(v_{\text {ini,sinm }, X}-v_{\text {sinm }, X}\right), \\
\frac{d Z}{d t}=-v_{Z, m R N A}, v_{Z, m R N A} \sum_{X=P, R, C, D, M}\left(v_{\text {ini, sinm }, X}+\Delta_{Z, \text { sinm }, X} v_{\text {sinm }, X}\right), \\
v_{\text {ini,sinm }, X}=k_{\text {inim }, X}\left[G_{X}-\frac{X_{m, b u f}}{n_{p, X}}\right] \frac{W_{P}}{K_{P, X} V+W_{P}} \frac{Z}{K_{Z, \text { inim }, X} V+Z}- \\
-v_{\text {sinm }, X}=k_{\text {sinm }, X} X_{m, b u f} \frac{Z}{K_{Z, b u f n, X} V+Z}
\end{array}\right), X=P, R, C, D, M .
$$


The first equation in (3) describes the initiation of mRNA synthesis $\left(v_{i n i, \sin , X}\right)$ and the elongation-termination of mRNA synthesis $\left(v_{\operatorname{sinm}, X}\right)$. The second equation describes the process of mRNA synthesis. The third equation considers RNA polymerases consumption during synthesis initiation and their release during transcription termination. The fourth equation considers consumption of the nutrient $Z$ in the process of mRNA synthesis (for more details on this model variable, see subsystem 6).

Let us justify the representation of functions $v_{\text {ini,sinm }, X}$ and $v_{\text {sinm }, X}$. We consider that those promoters free of elongating RNA polymerases are available for the initiation of transcription. The proportion of promoter sites that are fully or partially occupied by elongating RNA polymerases was calculated as a ratio between the number of elongating RNA polymerases $X_{m, b u f}$ and the maximum possible number of RNA polymerases capable of simultaneously transcribing one gene $n_{p, X}$ (this parameter was calculated as the length of the transcribed portion of the gene divided by the number of nucleotides covered by one elongating RNA polymerase).

As a result, proportion of promoters available for initiation of transcription was calculated using the formula $\left[G_{X}-\frac{X_{m, b u f}}{n_{p, X}}\right]$, where $G_{X}$ is the number of promoters of the gene $X$. Let us assume that during the transcription initiation, RNA polymerases and the resource represent a substrate, and free promoters represent an enzyme. The simplest possible Michaelis-Menten equation was used to describe such process. As a result, we obtained the desired representation of the function $v_{\text {ini,sinm }, X}$.

The same considerations were used to derive the $v_{\text {sinm }, X}$ function. In this case, elongating complexes $X_{m, b u f}$ represent an enzyme, and generalized resource $Z$ represents a substrate. At the same time, among large number of identical reactions of nucleotide attachment to the growing chain, we considered only one reaction; and the number of consumable molecules of the generalized resource was considered via parameter $\Delta_{Z, \text { sinm }, X}$.

Subsystem (3) - protein synthesis. We suppose that initiation of protein synthesis occurs in the mRNA regulatory regions (analogues of SD-box); the result of initiation is the elongating complex, which after a while generates one protein molecule. Protein synthesis was described by the following equations:

$$
\left\{\begin{array}{l}
\frac{d X_{b u f}}{d t}=v_{i n i, s i n, X}-v_{s i n, X}, X=P, R, C, D, M, \\
\frac{d X}{d t}=v_{s i n, X}, \quad X=P, R, C, D, M, \\
\frac{d W_{C}}{d t}=-\sum_{X=P, R, C, D, M}\left(v_{i n i, s i n, X}+v_{s i n, X}\right), \\
\frac{d Z}{d t}=-v_{Z, p r t}, \quad \\
v_{Z, p r t}=\sum_{X=P, R, C, D, M}\left(v_{i n i, s i n, X}+\Delta_{z, s i n, X} v_{s i n, X}\right), \\
v_{i n i, s i n, X}=k_{i n i, X}\left[X_{m R N A}-\frac{X_{b u f}}{m_{C, X}}\right] \frac{W_{C}^{2}}{\left(K_{C, X} V\right)^{2}+K_{C, X} V W_{C}+W_{C}^{2}} \frac{Z}{K_{Z, i n i, X} V+Z}, X=P, R, C, D, M, \\
v_{s i n, X}=k_{s i n, X} X_{b u f} \frac{Z}{K_{Z, s i n, X} V+Z}, X=P, R, C, D, M .
\end{array}\right.
$$


Analogous arguments used to derive equations (3) were used to derive functions $v_{\text {ini,sin, } X}$ and $v_{\sin , X}$. Moreover, it was considered that two ribosomal subunits participate in the initiation of translation: large and small. Therefore, instead of a linear fraction, quadratic fraction was used to describe assembly of the ribosomal elongation complex.

Parameters in the equations (3) and (4) have the following meanings: $K_{C, X, I}-$ MichaelisMenten constants, $k_{\text {inim }, X}, k_{\text {ini,X }}-$ initiation rate constants, $k_{s i n m, X}, k_{s i n, X}-$ rate constants for mRNA and protein synthesis.

Subsystem (4) - growth of cell wall and cell volume. Cell wall growth was described by the exponential mechanism, according to which the growth rate of the wall is proportional to the product of the area by the concentration of the cytoplasmic structural factor:

$$
\left\{\begin{array}{l}
\frac{d W_{R}}{d t}=-v_{R, Z, S}, \\
\frac{d S}{d t}=k_{\text {grow }} v_{R, Z, S}, \\
\frac{d Z}{d t}=-\Delta_{R, Z, S} v_{R, Z, S}, \\
v_{R, Z, S}=k_{S} \frac{W_{R}}{V} \frac{Z}{K_{Z, S} V+Z} S .
\end{array}\right.
$$

In (5) $k_{S}$ is the rate constant for the incorporation of the growth factor molecule into the cell wall, $k_{\text {grow }}$ denotes the scale coefficient for the growth of the area $\left(\mu \mathrm{m}^{2}\right)$ per molecule. The model is based on the cylindrical cell with flat ends, the growth of which is due to an increase in the area of the cylindrical part of the shell. The cell volume was calculated by the formula:

$$
V=\rho S .
$$

Here $\rho$ is half the radius of the cylinder. Part of the cell cycle in which parent cell divides into two daughter cells was neglected.

Subsystem (5) - degradation of mRNA and proteins. Let us assume that mRNA and proteins have finite lifetimes. Constitutional decay (loss of functionality) of molecules was described by linear laws:

$$
\left\{\begin{array}{l}
\frac{d X_{m R N A}}{d t}=-v_{\operatorname{degrm}, X}, k_{\operatorname{degrm}, X}=X_{m R N A}, \\
\frac{d X}{d t}=-v_{\operatorname{deg}, X}, v_{\operatorname{degr}, X}=k_{\operatorname{degr}, X} X .
\end{array}\right.
$$

Dynamic decay of molecules, carried out by nucleases and proteases, was also considered in the model. Generalized degradation factor, the active form of which is the WD complex, performed this role in the model. Dynamic decay was described by the equations:

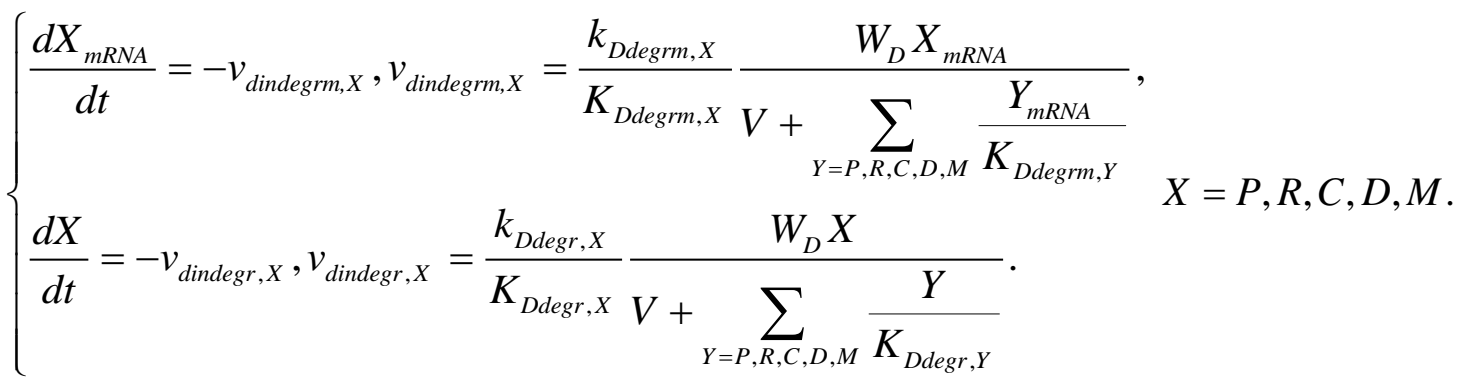


We did not look at the decay of the complexes.

Subsystem (6) - generalized nutrient resource. We believe that during its life cycle the cell consumes a generalized resource (analog, glucose), from which it synthesizes DNA, RNA and proteins and builds all cellular components and structures. Let us assume that nutrients enter the cell from the external environment, at a rate that is proportional to the cell wall area $S$. The amount of nutrients inside the cell we denote by $Z$. Processes by which a cell converts nutrients into low-molecular substances (nucleotides, amino acids, etc.) were neglected. We assume that intracellular fraction of nutrients represents a universal building element of all cellular components.

Additional to equations describing nutrients consumption during mRNA, protein and cell wall synthesis (see (3)-(5)), we have equations describing nutrients flow into the cell $\left(v_{Z, \text { in }}\right)$, outflow from the cell $\left(v_{Z, i n}\right)$ and nutrients consumption during genomic DNA replication $\left(v_{Z, u t i l, D N A}\right)$ :

$$
\begin{aligned}
& \frac{d Z}{d t}=v_{Z, \text { in }}-v_{Z, \text { out }}-v_{Z, \text { util }, D N A}, \\
& v_{Z, \text { in }}=k_{\text {in }, Z} S, v_{Z, \text { out }}=k_{\text {out }, Z} \frac{Z}{V} S, v_{Z, \text { util }, D N A}=k_{Z, D N A}\left(d_{O R I}-d_{T E R M}\right) .
\end{aligned}
$$

where $d_{O R I}$ - number of replication initiation sites in the cell at the current time, $d_{T E R M}-$ number of replication termination sites, $\left(d_{O R I}-d_{T E R M}\right)$ - number of replication forks, in which nutrients consumption in the process of genomic DNA replication occurs.

Subsystem (7) - initiation and elongation of replication. Initiation of replication was described in the model as a one-time double increase of the current number of $d_{O R I}$ replication initiation sites (ORI) at the moment the cell reaches the volume $V=D_{i n v} \cdot d_{O R I}\left(D_{i n v}-\right.$ Donachi invariant, [27]). At this time point, $2 d_{O R I}$ of new replication forks arise that move along the genome at a rate that provides doubling of the genome in a time $T_{i n v}\left(T_{i n v}\right.$ - CooperHelmstetter replication invariant, [28]). For each gene, we determine the distance to the ORI site dist $_{X}$ in units of time that is required for the replication fork to reach the designated gene. At this point, the number of genes $G_{X}$ is doubled. $T_{i n v}$ after the replication initiation replication forks reach the termination site of the replication. At this moment, the current number of genomes doubles and the number of replication forks decreases by the number of terminated ones.

Subsystem (8) - cell division. The cell is divided after not less than $D_{i n v}$ time units have passed since the appearance of two genome copies in the cell $\left(D_{i n v}-\right.$ Cooper-Helmstetter division invariant [28]). If at this moment the cell volume is $V \geq 2 \cdot V_{\min }$, then the division takes place. At this moment, all absolute indices of the cell are divided in half. If $V<2 \cdot V_{\min }$, the cell continues to grow until it reaches a minimum critical volume of $2 \cdot V_{\min }$.

Subsystem (9) - general system that describes bacteria cell functioning at the current time of the cell cycle. Equations (2)-(9) describe local rates of change in amounts of the corresponding cell substances, determined by specific processes. To describe global rates of change in amounts of substances at the current time of the cell cycle, it is necessary to summarize all local velocities for each substance (the velocity addition law). As a result, to define laws of change in absolute amounts of substances in a cell, we receive the following system of equations: 


$$
\begin{aligned}
& \int \frac{d S}{d t}=\Delta_{\text {grow }} v_{R, Z, S} \\
& \frac{d X_{m, b u f}}{d t}=v_{\text {ini,sinm }, X}-v_{\text {sinm }, X}, \quad X=P, R, C, D, M, \\
& \frac{d X_{m R N A}}{d t}=v_{\sin , X}-v_{\text {degrm }, X}-v_{\text {dindegrm }, X}, \quad X=P, R, C, D, M, \\
& \frac{d X_{b u f}}{d t}=v_{i n i, \sin , X}-v_{\sin , X}, \quad X=P, R, C, D, M, \\
& \frac{d X}{d t}=v_{\sin , X}-n_{1, X} v_{W_{X}}-v_{d e g r, X}-v_{\text {dindegr }, X}, \quad X=P, R, C, D, M, \\
& \frac{d W_{P}}{d t}=v_{W_{P}}-\sum_{X=P, R, C, D, M}\left(v_{i n i, \operatorname{sinm}, X}-v_{\text {sinm }, X}\right), \\
& \frac{d W_{R}}{d t}=v_{W_{R}}-v_{R, S} \\
& \frac{d W_{C}}{d t}=v_{W_{C}}-\sum_{X=P, R, M, C}\left(v_{i n i, \sin , X}-v_{\sin , X}\right), \\
& \frac{d W_{D}}{d t}=v_{W_{D}} \\
& \frac{d Z}{d t}=v_{Z, i n}-v_{Z, \text { out }}-\Delta_{R, Z, S} v_{R, Z, S}-v_{Z, u t i l, D N A}-v_{Z, m R N A}-v_{Z, p r t} .
\end{aligned}
$$

\subsection{Calculation method of the model}

An original FORTRAN program was developed for calculating the model. Calculations were carried out for cells arising as a result of successive division. The system (10) calculation started from the given initial state at the zero time point. Numerical integration of the system (10) was carried out at finite time intervals. Boundaries of the intervals were the time points in which either the value of one of the parameters $d_{\text {ORI }}, d_{\text {TERM }}, G_{X}, X=$ $P, R, M, C, D$ changed, or cell division occurred. At these points in time, integration of the system (10) was interrupted. Depending on the conditions, either values of the parameters $d_{O R I}, d_{T E R M}, G_{X}$ were changed, or the initial state of the daughter cell was calculated. After that, integration of the system (10) was resumed with new values of the parameters $d_{\text {ORI, }}$, $d_{T E R M}, G_{X}$, or with new initial data. For the calculation, a semi-implicit scheme was used that ensures the law of conservation of the number of particles and guarantees the positivity of the solution if the initial data are nonnegative. The difference scheme is given in the Appendix.

\subsection{Estimation of model parameters}

Parameters of the replication, transcription, translation, formation of protein complexes, mRNA and protein degradation were evaluated from literature data, based on the average statistical values characteristic of bacterial cells [29-37]. When assessing parameters of growth and cell division, we focused mainly on E. coli and closely related species [27-29]. Prototype of the structural protein of the shell ${ }^{\circledR}$ was considered the most representative cell wall protein Lpp [38]. Parameters used are shown in Tables 1 and 2. 


\section{ANALYSIS OF THE DYNAMICS OF FUNCTIONING OF THE MODEL OF BACTERIAL CELL CYCLE}

\subsection{Degenerative scenario of the cell cycle}

Let us note that for any set of parameter values model (10) has a so-called degenerate phenotype. It is characterized by zero amounts of mRNA and proteins. Since all biological molecules are damaged over time (as a result of collisions with other molecules), values of rate constants for the constitutive decay of mRNA and proteins in the model (10) are greater than zero. This implies that degenerate phenotype is locally stable.

On the content level, this implicates that for any set of parameter values there is positive probability that during division, due to random fluctuations, daughter cell can receive enough dissolved substances for it to gain a potential for developing a degenerate phenotype. After that, slowly (maybe after several cycles of division) cell's metabolism slows down so much that the cell stops dividing. However, the cell degeneration continues, since natural loss of active molecules in the cell is not replenished by their de novo synthesis. This outcome can be interpreted as loss of vitality and death.

Since the existence of a degenerate phenotype is undoubtable, it became clear that de facto the area of its attraction can not be too big. This conclusion follows from experimental observations that indicate a very high cell viability and association of their premature death with other causes, rather than with the cell entering the degeneration area.

To get a rough idea of the probability of degenerate phenotype realization, let us perform the following thought experiment. Imagine that there is no ribosome in the cell. Then, regardless of the values of other substances concentrations, translation will not occur in the cell, which, in the end, will lead to cell death. That is, a sufficiently small amount of ribosomes ensures that the cell enters the degeneration area. We now turn to the model (10). In it, ribosomes represent complexes of generalized ribosomal protein $\mathrm{C}$. Protein $\mathrm{C}$, in turn, is produced from mRNA under the control of ribosomes. We linearize the right-hand side of the equation of the ribosomal protein $\mathrm{C}$ production/degradation rate near zero. After simplifications, we find the following equation:

$$
\frac{d C}{d t}=k_{i n i, C} m R N A_{C}\left(\frac{C}{K_{C, C}}\left(\frac{C}{K_{D, W C}}\right)^{n_{C}-1}\right)^{2}-k_{d e g r, C} C
$$

From it, we calculate the upper approximation for the protein $\mathrm{C}$ degeneracy point:

$$
\left(\frac{C}{K_{D, W C}}\right)^{2 n_{C}-1} \leq \frac{k_{d e g r, C}\left(K_{C, C}\right)^{2}}{k_{i n i, C} m R N A_{C} K_{D, W C}}
$$

Let us estimate possible value of the given number. To do this, let us assume that there are $m R N A_{C}$ molecules in the cell (otherwise, the right-hand side of the inequality equals infinity, which is equivalent to its automatic implementation for any values of $C$ ). For definiteness, we assume that their minimum possible number is one molecule per cell. Values of other parameters we take from Table 1.

$$
\left(\frac{C}{K_{D, W C}}\right)^{2 n_{C}-1} \leq \frac{10^{-7}\left(7 \cdot 10^{3}\right)^{2}}{5.5 \cdot 10^{-1} \cdot 100}=\frac{0.49}{5.5} \Rightarrow \mathrm{C} \leq 99 .
$$

From the obtained estimate, we identify that the degeneracy threshold based on the amount of free ribosomal protein is close to the value of $K_{D, W X}$ (generalized constant for the dissociation of large and small ribosomal subunits into protein constituents) (Table 1). This ratio is determined by the high degree of multimerization of ribosomal subunits, which is 
assumed in the model to be $n_{C}=25$. In this case, the number of free ribosomal subunits is estimated to be

$$
W_{C}=C\left(\frac{C}{K_{D, W C}}\right)^{n_{C}-1} \leq C\left(\frac{0.49}{5.5}\right)^{\frac{n_{C}-1}{2 n_{C}-1}} \sim 1
$$

It seems fairly obvious that if a cell functions in the parameter area shown in Table 1, appearance of a cell with extremely small amount of ribosomes (one per cell) is a very rare event. However, with other relative parameter ratios, probability of degeneration can be very high; nonetheless, a more detailed analysis of the degenerate phenotype is beyond the scope of our study.

\subsection{Nondegenerate cell cycle phenotype}

In this section, we demonstrate that when values taken by the parameters are in the physiological range of the rates of molecular and biochemical processes in prokaryotic cells, model (10) allows calculating the nondegenerate cell cycle scenario with characteristics observed in many natural cells. One of these variants of parameter values is given in Tables 1 and 2 .

Table 1. List of model (10) parameters and parameter values for which model (10) has a stationary cell cycle with duration $T \sim 20 \mathrm{~min}$

\begin{tabular}{|c|c|c|c|}
\hline $\begin{array}{l}\text { Formula } \\
\text { № }\end{array}$ & Parameter $^{\mathrm{a}}$ & Definition of parameter & Value $^{b}$ \\
\hline 1 & 2 & 3 & 4 \\
\hline 1,2 & $k_{X W}$ & $\begin{array}{l}\text { rate constant for formation of an active complex } W_{X}, \\
X=P, R, C, D\end{array}$ & $10 \sec ^{-1}$ \\
\hline 2 & $K_{D, W X}$ & $\begin{array}{l}\text { equilibrium dissociation constant for the active } \\
\text { complex } W_{X} \text {, where } X=P, R, C, D \text { are monomers }\end{array}$ & $100 \mathrm{pcs} . / \mu \mathrm{m}^{3}$ \\
\hline 1,2 & $n_{X}$ & $\begin{array}{l}\text { multimerity of functionally active complexes } W_{X}, \\
X=P, R, C, D\end{array}$ & $4,3,25,4$ pcs. \\
\hline 2 & $n_{1, X}$ & $\begin{array}{l}\text { number of monomers } X \text { in the complex } W_{X} \text {, } \\
X=P, R, C, D\end{array}$ & $1,3,1,4$ pcs. \\
\hline \multirow{6}{*}{3} & $k_{\text {inim }, X}$ & rate constant for initiation of mRNA synthesis & $\begin{array}{l}0.1,0.2,0.2 \\
0.2,0.2 \mathrm{sec}^{-1}\end{array}$ \\
\hline & $k_{\text {sinm }, X}$ & rate constant for mRNA synthesis & $0.1 \mathrm{sec}^{-1}$ \\
\hline & $K_{P, X}$ & $\begin{array}{l}\text { Michaelis constant for RNA polymerase involvement } \\
\text { in the process of transcription initiation from gene } X\end{array}$ & $500 \mathrm{pcs} . / \mu \mathrm{m}^{3}$ \\
\hline & $K_{Z, \text { inim }, X}$ & $\begin{array}{l}\text { Michaelis constant for the resource } \mathrm{Z} \text { consumption } \\
\text { during initiation of gene } X \text { transcription }\end{array}$ & 110 c. $\mathrm{u} . / \mu \mathrm{m}^{3}$ \\
\hline & $K_{Z, b u f m, X}$ & $\begin{array}{l}\text { Michaelis constant for the resource } \mathrm{Z} \text { consumption } \\
\text { during elongation of gene } X \text { transcription }\end{array}$ & 110 c. u. $/ \mu \mathrm{m}^{3}$ \\
\hline & $n_{P, X}$ & $\begin{array}{l}\text { maximum number of RNA polymerases per gene } X \\
\text { during elongation }\end{array}$ & 10 pes. \\
\hline \multirow{6}{*}{4} & $k_{i n i, X}$ & rate constant for initiation of protein synthesis & $\begin{array}{l}0.1,0.4,0.55,0.04 \\
0.1 \mathrm{sec}^{-1}\end{array}$ \\
\hline & $k_{s i n, X}$ & rate constant for protein synthesis & $0.1 \mathrm{sec}^{-1}$ \\
\hline & $K_{C, X}$ & $\begin{array}{l}\text { Michaelis-Menten constant for the participation of } \\
\text { ribosomal subunits in the process of translation } \\
\text { initiation }\end{array}$ & $\begin{array}{c}5000,500,7000 \\
5000,10000 \mathrm{pcs} . / \mu \mathrm{m}^{3}\end{array}$ \\
\hline & $K_{Z, i n i, X}$ & $\begin{array}{l}\text { Michaelis-Menten constant for the resource } Z \\
\text { consumption during initiation of gene } X \text { translation }\end{array}$ & 110 c. u. $/ \mu \mathrm{m}^{3}$ \\
\hline & $K_{Z, b u f, X}$ & $\begin{array}{l}\text { Michaelis constant for the resource } Z \text { consumption } \\
\text { during elongation of gene } X \text { translation }\end{array}$ & 110 c. u. $/ \mu \mathrm{m}^{3}$ \\
\hline & $m_{C, X}$ & $\begin{array}{l}\text { maximum number of ribosomes per gene } X \text { mRNA } \\
\text { reading frame }\end{array}$ & 10 pes. \\
\hline
\end{tabular}


Continuation of Table 1. List of model (10) parameters and parameter values for which model (10) has a stationary cell cycle with duration $T \sim 20 \mathrm{~min}$

\begin{tabular}{|c|c|c|c|}
\hline 1 & 2 & 3 & 4 \\
\hline \multirow{4}{*}{5} & $k_{S}$ & $\begin{array}{l}\text { rate constant for the incorporation of the growth } \\
\text { factor molecule into the cell membrane }\end{array}$ & $1 \mathrm{sec}^{-1}$ \\
\hline & $K_{Z, S}$ & $\begin{array}{l}\text { Michaelis constant for the resource } Z \text { consumption } \\
\text { during the cell membrane growth }\end{array}$ & 110 c. u. $/ \mu \mathrm{m}^{3}$ \\
\hline & $k_{\text {grow }}$ & $\begin{array}{l}\text { growth coefficient for the increase of the membrane } \\
\text { area per one molecule of growth factor, } \mu \mathrm{m}^{2}\end{array}$ & $0.00058 \mu \mathrm{m}^{2}$ \\
\hline & $\Delta_{R, Z, S}$ & $\begin{array}{l}\text { number of conventional units of the resource spent } \\
\text { per one unit of growth factor } W_{R} \text {, incorporated in the } \\
\text { membrane }\end{array}$ & 1 c. u. \\
\hline 6 & $\rho$ & half the radius of the cell & $0.25 \mu \mathrm{m}$ \\
\hline 7 & $k_{\operatorname{deg} r, X}$ & $\begin{array}{l}\text { rate constant for the protein } X \text { constitutive } \\
\text { degradation }\end{array}$ & $0.000001 \mathrm{sec}^{-1}$ \\
\hline \multirow{4}{*}{8} & $k_{D d e g r, m X}$ & $\begin{array}{l}\text { rate constant for the gene } X \text { mRNA degradation by } \\
\text { cellular nucleases }^{c}\end{array}$ & $\begin{array}{c}0.0029,0.00029 \\
0.0029,0.0029 \\
0.0058 \mathrm{sec}^{-1}\end{array}$ \\
\hline & $K_{D \operatorname{deg} r, m X}$ & $\begin{array}{l}\text { Michaelis constant for the gene } X \text { mRNA degradation } \\
\text { by cellular nucleases }{ }^{c}\end{array}$ & $2900 \mathrm{pcs} . / \mu \mathrm{m}^{3}$ \\
\hline & $k_{D \operatorname{deg} r, X}$ & $\begin{array}{l}\text { rate constant for the protein } X \text { degradation by cellular } \\
\text { proteases }^{\text {c }}\end{array}$ & $\begin{array}{c}0.0011,0,0.0011 \\
0.0029,0.0029 \mathrm{sec}^{-1}\end{array}$ \\
\hline & $K_{D d e g r, X}$ & $\begin{array}{l}\text { Michaelis constant for the protein } X \text { degradation by } \\
\text { cellular proteases }^{c}\end{array}$ & $2900 \mathrm{pcs} . / \mu \mathrm{m}^{3}$ \\
\hline \multirow{3}{*}{9} & $k_{i n, Z}$ & $\begin{array}{l}\text { rate constant for the inflow of nutrient resource into } \\
\text { the cell }\end{array}$ & $\begin{array}{c}120000 \\
\text { c. } \mathrm{u} . /\left(\mathrm{sec} \cdot \mu \mathrm{m}^{3}\right) \\
\end{array}$ \\
\hline & $k_{\text {out }, \mathrm{Z}}$ & $\begin{array}{l}\text { rate constant for the outflow of nutrient resource } \\
\text { from the cell }\end{array}$ & 100 c. u./sec \\
\hline & $k_{Z, D N A}$ & $\begin{array}{l}\text { specific rate constant for the resource consumption } \\
\text { during genomic DNA replication }\end{array}$ & 1 c. u./sec \\
\hline
\end{tabular}

${ }^{a} X=P, R, C, D, M$, unless otherwise specified.

${ }^{\mathrm{b}}$ If a single number is represented in the graph, then values of all specified parameters are equal to it, otherwise values are indicated in the order of the index $X$ value change.

${ }^{\mathrm{c}}$ In the model, nuclease and protease activities are carried out by a single generalized protein $W_{D}$.

Table 2. Characteristics of the genome and cellular invariants

\begin{tabular}{|c|c|l|c|}
\hline $\begin{array}{c}\text { Subsystem } \\
\text { № }\end{array}$ & Parameter & \multicolumn{1}{|c|}{ Definition of parameter } & Value \\
\hline & $\begin{array}{c}d_{\text {Ori }}, d_{T E R M} \\
g_{X}\end{array}$ & $\begin{array}{l}\text { Number of copies of replication initiation } \\
\text { and termination sites, and genes } g P, g C, \\
g R, g M, \text { and } g D \text { in the genome }\end{array}$ & $1,1,1,1,500$ pcs. \\
\hline 7 & $d_{i s t_{X}}$ & $\begin{array}{l}\text { distance of the gene X from the origin of } \\
\text { replication (calculated as the time from the } \\
\text { moment of replication initiation to the } \\
\text { moment of gene } X \text { doubling) }\end{array}$ & $600,1200,600,1200,1200 \mathrm{sec}$ \\
\hline 7,8 & $V_{i n v}$ & $\begin{array}{l}\text { Cell volume per one replication initiation } \\
\text { site, when it exceeds the initiation of } \\
\text { genome replication starts }\end{array}$ & $1.5 \mu \mathrm{m}^{3}$ \\
\hline 7,8 & $T_{i n v}$ & duration of the genome replication & $2400 \mathrm{sec}$ \\
\hline 7,8 & $D_{i n v}$ & cell division duration & $1200 \mathrm{sec}^{2}$ \\
\hline
\end{tabular}

Main features of the cell cycle calculated according to the model (10) are presented in the first column of the Table 3 for a given set of parameter values. We shall note that given phenotype has a short cell cycle $(T \sim 20 \mathrm{~min})$, large volume of the newborn cell $\left(V \sim 6.1 \mu \mathrm{m}^{3}\right)$, intensive replication (eight replication forks at the beginning of the cell cycle) and intensive 
metabolism (tens of thousands of RNA polymerase molecules and more than a hundred thousands of ribosomes). Data presented in Table 3 also demonstrate the dependence of phenotypic characteristics on the availability of the nutrient resource. Note that calculated characteristics vary in accordance with the expectations developed during experimental observations: as the resource deficit increases, duration of the cell cycle increases, cell size decreases, intensity of replication and metabolism decreases [39]. From the data presented, we conclude that characteristics of the calculated phenotype correlate well with the corresponding parameters of E. coli, S. typhimurium and B. subtilis cells developing in a rich medium [27, 28, 39-41]. We named this scenario the R-phenotype (Rapid-phenotype).

Table 3. Dependence of phenotypic characteristics on the variations in the rate of resource entry into the cell

\begin{tabular}{|c|c|c|c|c|c|c|c|c|}
\hline \multirow{2}{*}{$\begin{array}{c}\text { Cell cycle } \\
\text { characteristics }\end{array}$} & \multicolumn{8}{|c|}{ Availability of nutrient resource $k_{i n, Z}$} \\
\hline & \multicolumn{2}{|c|}{132000} & \multicolumn{2}{|c|}{59500} & \multicolumn{2}{|c|}{40000} & \multicolumn{2}{|c|}{25000} \\
\hline Phenotypes & $\mathrm{R}$ & $\mathrm{S}$ & $\mathrm{R}$ & $\mathrm{S}$ & $\mathrm{R}$ & $\mathrm{S}$ & $\mathrm{R}$ & $\mathrm{S}$ \\
\hline Duration (min) & 20 & 2136 & 30 & 2684 & 40 & 3118 & 60 & 3836 \\
\hline Cell volume $\left(\mu \mathrm{m}^{3}\right)$ & 6.1 & 1 & 3.0 & 1 & 2.2 & 1 & 1.5 & 1 \\
\hline Number of ribosomes ${ }^{\mathrm{a}}$ & 127200 & 170 & 46300 & 162 & 27500 & 162 & 15200 & 160 \\
\hline $\begin{array}{c}\text { Number of RNA } \\
\text { polymerases }^{\mathrm{a}}\end{array}$ & 27800 & 30 & 13300 & 29 & 8800 & 29 & 5200 & 29 \\
\hline $\begin{array}{l}\text { Number of replication } \\
\text { initiation sites }\end{array}$ & 8 & 1 & 4 & 1 & 2 & 1 & 2 & 1 \\
\hline Relative genome mass ${ }^{b}$ & $7 / 3$ & 1 & $5 / 4$ & 1 & $3 / 2$ & 1 & 1 & 1 \\
\hline
\end{tabular}

${ }^{a}$ at the moment of cell birth;

${ }^{\mathrm{b}}$ mass of one copy of genome was taken as one unit.

\subsection{Second nondegenerate phenotype of the cell cycle}

A remarkable property of the set of parameter values given in Table 1 is that, in addition to the cell cycle scenarios described above, another nondegenerate stable scenario exists in the model (10). Unlike R-phenotype, this scenario is characterized by slow growth, prolonged cellular cycle and low replicative and metabolic activity (Table 3). Therefore, we designated this scenario as S-phenotype (Slow-phenotype). According to its characteristics, S-phenotype is similar to the so-called persistent phenotype of natural cells [20].

Thus, in model (10), a single cell cycle is carried out not in one, but at least in two nontrivial ways. Numerically, both R-and S-phenotypes are stable, that is, a nontrivial area of attraction exists for each of them. Each cell at the initial moment of birth has a certain set of concentrations, substances dissolved in it, and the phenotype of its cell cycle depends on the area of attraction.

\subsection{Biological interpretation of modeling results}

Let us apply modeling results to real cells. Let us consider a cell with the set of parameter values that allows carrying out the cell cycle in two different ways and assume that such cell exists in optimal external conditions. In this case, a population of cells derived from such cell will mostly consist of large, fast-growing cells with short cell cycles. In terms of the model developed above, these will be cells with R-phenotype. However, from time to time, small, slowly growing and rarely dividing, but at the same time completely viable cells will appear in the population. Such cells we identify as cells that grow differently and have, what we called, S-phenotype.

In addition, a third cell type will occur in these populations of cells at vanishingly low frequency. They are also small, but the intensity of metabolism gradually decreases it these cells until the viability is lost completely. Moreover, such suicide cells appear without 
apparent cause, since the only driving factor in the implementation of such a scenario is the inevitable fluctuations appearing during the redistribution of dissolved substances of the parent cell between daughter cells.

\section{DISCUSSION}

The present work introduces a deterministic model of prokaryotic cell cycle. In the model, the cell cycle duration is controlled by the cell size and the presence of two or more complete copies of genomic DNA. Rates of cell volume growth and DNA replication were reconciled on the basis of the Donachi phenomenological growth law of initiator mass constancy [27]; durations of replication and division were determined in accordance with the Cooper and Helmstetter invariants [28], which are being successfully used in modeling of prokaryotic cell cycle [42-44].

We present a set of parameter values, which allow carrying out cell cycle in at least two different ways: R- and S-phenotypes. Cells with R-phenotype divide quickly, have large sizes and are characterized by intensive replication and metabolism. S-cells, on the contrary, divide rare, have small sizes and have low levels of metabolism and replication. The ability to have two phenotypes can be realized in the model, in which intracellular processes are described without involving feedback mechanisms that create special conditions for the formation of bistability. Hence, we assume that observed phenotypic multiplicity represents an intrinsic, immanent property of bacteria, and universal nonlinear properties of the conjugated transcription-translation system, under the control of which all processes of the cell cycle take place, lie at the basis of this phenomenon.

Thus, based on the model analysis, we predict that under the same conditions the same natural cell can carry out cell cycle in more than one way. That is, the cell can implement the following principle of reproduction: one genotype $\rightarrow$ two phenotypes. At the same time, as bacteria are nonlinear, dynamic, dissipative and self-reproducing systems, general principles of their hereditary information storage and transfer, as well as fundamental biochemical laws of functioning, are sufficient for the realization of such principle of reproduction and do not require any special molecular genetic regulatory trigger mechanisms. Obviously, this form of reproduction is more complex, in comparison with one genotype $\rightarrow$ one phenotype principle of reproduction.

Let us discuss whether cells that during division implement one genotype $\rightarrow$ two phenotypes principle have any advantages over cells that produce single phenotype during division.

Let us point out that in nature cells exist in inconstant environmental conditions and are regularly exposed to stressful influences. It is logical to assume that actively growing cells with high levels of metabolism and replication are more susceptible to the environmental stresses, compared to slowly growing cells with low levels of replication and metabolism. That is, R-phenotype is more susceptible to stress than S-phenotype. In other words, the biphenotypic principle of reproduction has an evolutionary advantage over the monophenotypic one.

In our opinion, this statement is strongly supported by experimental and theoretical studies of the adaptation of $E$. coli cells to environmental conditions. It was demonstrated that under transition from one nutrient resource to another, and also under nutrient deficiency, that is, under stress, a phenotypic heterogeneity in bacterial growth rates, and, therefore, in metabolic rates, is observed in a genetically homogeneous population [17, 18]. We hypothesize that possibility to carry out cell cycle in two different ways has not only been implemented numerous times in natural cells, but has also been established at the genetic level via the emergence of specific molecular genetic mechanisms that in various species are characterized by a significant variety. Such a property is possessed, for example, by trigger mechanisms, widely distributed in living organisms, organized by a feedback type, and characteristic of 
many stress-regulated systems, including toxin-antitoxin system (see review [45]). It is therefore not surprising that peculiarities of functioning of these systems [22-24] are thought to be associated with mechanisms of emergence of cells possessing a persistent phenotype $[20,46,47]$, the general characteristic of which agrees so well with the predicted S-phenotype of the cell cycle (see section 2.3).

The proposed hypothesis of the origin of bimodal cellular distribution according to growth rate, cell size and metabolic level allows illustrating the characteristics of persistent cells [20, $46,47]$ based on the basic properties of the transcription-translation system inherent in all living organisms. In this sense, our hypothesis is universal and is applicable to evolutionarily distant prokaryotes.

The work was partially supported by the Russian Foundation for Basic Research (№ 16-01-00237) and the project of fundamental research of the SB RAS "Genetic bases of molecular genetics, cell biology, bioinformatics and biotechnology" № 0324-2015-0003. 


\section{APPENDIX.}

DIFFERENCE SCHEME FOR NUMERICAL INTEGRATION OF THE SYSTEM OF EQUATIONS (10)

Let us introduce the following notation for the concentration of substances: $p=P / V$, $r=R / V, \quad m=M / V, \quad c=C / V, \quad d=D / V, \quad z=Z / V, \quad p_{b u f}=P_{b u f} / V, \quad r_{b u f}=R_{b u f} / V, \quad c_{b u f}=C_{b u f} / V$, $d_{b u f}=D_{b u f} / V, m_{b u f}=M_{b u f} / V, p_{m, b u f}=P_{m, b u f} / V, r_{m, b u f}=R_{m, \text { buf }} / V, m_{m, \text { buf }}=M_{m, \text { buf }} / V, c_{m, \text { buf }}=C_{m, \text { buf }} / V$, $d_{m, b u f}=D_{m, b u f} / V, \quad \quad m_{r n a}=m R N A_{P} / V, \quad m r n a_{R}=m R N A_{R} / V, \quad m r n a_{C}=m R N A_{C} / V$, $m r n a_{M}=m R N A_{M} / V, m_{n} n_{D}=m R N A_{D} / V, g_{b u f, P}=G_{b u f, P} / V, g_{b u f, R}=G_{b u f, R} / V, g_{b u f, C}=G_{b u f, C} V$, $g_{b u f, M}=G_{b u f, M} / V, g_{b u f, D}=G_{b u f, D} / V, w_{P}=W_{P} / V, w_{R}=W_{R} / V, w_{C}=W_{C} / V, w_{M}=W_{M} / V, w_{D}=W_{D} / V$.

Also let us denote:

$$
\begin{aligned}
& \Psi_{m, X}=\frac{\left[\max \left(\frac{G_{X}}{V}-\frac{g_{\text {buf }, X}}{e_{P, X}}, 0\right)\right]}{K_{m, X}} \frac{z}{K_{Z, b u f n, X}+z} \frac{\left(\frac{w_{P}}{K_{m, X}}\right)^{h_{m, X}-1}}{1+\left(\frac{w_{P}}{K_{m, X}}\right)^{h_{m, X}}}, \quad X=P, R, M, C, D, \\
& \left\{\Psi_{X}=\frac{\left[\max \left(\text { mrna }_{X}-\frac{x_{b u f}}{e_{C, X}}, 0\right)\right]}{K_{X}} \frac{z}{K_{Z, b u f p, X}+z} \frac{\left(\frac{w_{C}}{K_{X}}\right)^{h_{X}-1}}{1+\left(\frac{w_{C}}{K_{X}}\right)^{h_{X}}}, \quad(x, X)=(p, P),(r, R),(m, M),(c, C),(d, D),\right. \\
& \psi_{S}=\frac{z}{K_{Z, S}+z}, \quad \psi_{\sin , X}=\frac{z}{K_{Z \sin m, X}+z}, \quad \psi_{\sin , X}=\frac{z}{K_{Z \sin , X}+z}, \quad X=P, R, M, C, D, \\
& \zeta_{X}=\left(\frac{x}{K_{D, X, W}}\right)^{n_{X}-1}, \quad(x, X)=(p, P),(r, R),(c, C),(d, D) \text {. } \\
& k_{d m, X}=k_{c d m, X}+k_{d m, D, X} \frac{w_{D}}{K_{d m, D, X}} \frac{\left(\frac{m r n a_{X}}{K_{d m, D, X}}\right)^{h_{d m, D, X}-1}}{1+\left(\frac{m r n a_{X}}{K_{d m, D, X}}\right)^{h_{d m, D, X}}}, X=P, R, M, C, D,, \\
& k_{d, X}=k_{c d, X}+k_{d, D, X} \frac{w_{D}}{K_{d, D, X}} \frac{\left(\frac{x}{K_{d, D, X}}\right)^{h_{d, D, X}-1}}{1+\left(\frac{x}{K_{d, D, X}}\right)^{h_{d, D, X}}}, \quad(x, X)=(p, P),(r, R),(m, M),(c, C),(d, D), \\
& k_{d, W_{X}}=k_{c d, W_{X}}+k_{d, D, W_{X}} \frac{w_{D}}{K_{d, D, W_{X}}} \frac{\left(\frac{w_{X}}{K_{d, D, W_{X}}}\right)^{h_{d, D, W_{X}}-1}}{1+\left(\frac{w_{X}}{K_{d, D, W_{X}}}\right)^{h_{d, D, W_{X}}}}, X=P, R, M, C, D,,
\end{aligned}
$$




$$
\begin{aligned}
& k_{\text {tott }, \text { util }}=\left(k_{\text {out }, Z} S+\Delta_{Z, S} k_{S} w_{R} \frac{1}{K_{S, Z}+z} \frac{S}{V}+\Delta_{g z} k_{\text {elong }, \text { repl }} \frac{\frac{G_{f}}{V}}{K_{\text {Zsin }, G_{f}}+z}+\sum_{\substack{X=P, R, M, C, D}}\left(\Delta_{\text {Zsinm }, G_{\text {buf }, X}} k_{\text {sinm }, X} \frac{\frac{G_{\text {buf }, X}}{V}}{K_{\text {Zsinm }, X}+z}+\right.\right. \\
& \left.\left.+\Delta_{z, \sin , X} k_{\text {sin }, X} \frac{x_{\text {buf }}}{K_{Z s i n, X}+z}\right)\right) .
\end{aligned}
$$

We rewrite system (10) from the text of the article with allowance for the introduced notations:

$$
\begin{aligned}
& \int \frac{d S}{d t}=\underbrace{\Delta_{S} k_{S} \frac{W_{R}}{V} \psi_{S} S}_{\substack{\text { рост } \\
\text { поверхности }}}-k_{\text {рециклизачия }} S, V=\rho S, \\
& \frac{d Z}{d t}=k_{\text {in,z }} S-\underbrace{k_{\text {pacxod pecypca }} Z}_{\text {influx }}, \\
& \frac{d G_{b u f, X}}{d t}=k_{b u f m, X} \psi_{m, X} W_{p}-k_{\text {sinm }, X} \psi_{\text {sinm }, X} G_{b u f, X}, \quad X=P, R, M, C, D, \\
& \frac{d m R N A_{X}}{d t}=k_{\text {sinm }, X} \psi_{\operatorname{sinm}, X} G_{b u f, X}-k_{d m, X} m R N A_{X}, \quad X=P, R, M, C, D, \\
& \left\{\frac{d X_{b u f}}{d t}=k_{b u f, X} \psi_{X} W_{C}-k_{s i n, X} \psi_{s i n, X} X_{b u f}, \quad X=P, R, M, C, D,\right. \\
& \frac{d X}{d t}=k_{s i n, X} \psi_{s i n, X} X_{b u f}+n_{1, X} k_{W X} W_{X}-\left(k_{d, X}+n_{1, X} k_{W X} \zeta_{X}\right) X, \quad X=P, R, C, M, D, \\
& \frac{d W_{P}}{d t}=k_{W P} \zeta_{P} P-\sum_{X=P, R, M, C, D}\left(\frac{d G_{b u f, X}}{d t}\right)-\left(k_{W P}+k_{d, W_{P}}\right) W_{P}, \\
& \frac{d W_{C}}{d t}=k_{W C} \zeta_{C} C-2 \sum_{X=P, R, M, C, D}\left(\frac{d X_{b u f}}{d t}\right)-\left(k_{W C}+k_{d, W_{C}}\right) W_{C} \text {, } \\
& \frac{d W_{D}}{d t}=k_{W D} \zeta_{D} X-\left(k_{W D}+k_{d, W_{C}}\right) W_{D}, \\
& \frac{d W_{R}}{d t}=k_{W R} \zeta_{R} R-\left(k_{W R}+k_{S} \psi_{S} \frac{S}{V}+k_{d, W_{R}}\right) W_{R} .
\end{aligned}
$$

Next, we write equations (A1), starting with third, in the difference form: 


$$
\left\{\begin{array}{l}
\frac{G_{b u f, X, 1}-G_{b u f, X, 0}}{h}=k_{s i n m, X} \psi_{s i n m, X, 0} W_{p, 1}-k_{b u f m, X} \psi_{m, X, 0} G_{b u f, X, 1}, \quad X=P, R, M, C, D, \\
\frac{m R N A_{X, 1}-m R N A_{X, 0}}{h}=k_{s i n m, X} \psi_{s i n m, X, 0} G_{b u f, X, 1}-k_{d m, X} m R N A_{X, 1}, \quad X=P, R, M, C, D, \\
\frac{X_{b u f, 1}-X_{b u f, 0}}{h}=k_{b u f, X} \psi_{X, 0} W_{C, 1}-k_{s i n, X} \psi_{s i n, X, 0} X_{b u f, 1}, \quad X=P, R, M, C, D, \\
\frac{X_{1}-X_{0}}{h}=k_{s i n, X} \psi_{s i n, X, 0} X_{b u f, 1}-h n_{1, X} k_{W X} W_{X, 1}+\left(k_{d, X}+n_{1, X} k_{W X} H_{X, 0}\right) X_{1}, \quad X=P, R, C, M, D, \\
\frac{W_{P, 1}-W_{P, 0}}{h}=\sum_{X=P, R, M, C, D} G_{b u f, X, 0}-\left(k_{W P}+k_{d, W_{P}}\right) W_{P, 1}-\sum_{X=P, R, M, C, D} G_{b u f, X, 1}-k_{W P} H_{P, 0} P, \\
\frac{W_{C, 1}-W_{C, 0}}{h}=k_{W C} \zeta_{C, 0} C_{1}+2 \sum_{X=P, R, M, C, D} X_{b u f, 0}-\left(k_{W C}+k_{d, W_{C}}\right) W_{C, 1}-2 \sum_{X=P, R, M, C, D} X_{b u f, 1}-h, \\
\frac{W_{D, 1}-W_{D, 0}}{h}=k_{W D} \zeta_{D, 0} X_{1}-\left(k_{W D}+k_{d, W_{C}}\right) W_{D, 1}, \\
\frac{W_{R, 1}-W_{R, 0}}{h}=k_{W R} \zeta_{R, 0} R_{1}-\left(k_{W R}+\frac{k_{S}}{\rho} \psi_{S, 0}+k_{d, W_{R}}\right) W_{R, 1},
\end{array}\right.
$$

Where

$$
\begin{aligned}
& G_{b u f, X, 1}=G_{b u f, X}(t+h), \quad G_{b u f, X, 0}=G_{b u f, X}(t), \\
& \psi_{S, 1}=\psi_{S}(t+h), \quad \psi_{S, 0}=\psi_{S}(t), \\
& \psi_{\text {sinm }, X, 1}=\psi_{\operatorname{sinm}, X}(t+h), \quad \psi_{\sin , X, 0}=\psi_{\operatorname{sinm}, X}(t), \\
& \psi_{\sin , X, 1}=\psi_{\sin , X}(t+h), \quad \psi_{\sin , X, 0}=\psi_{\sin , X}(t), \\
& m R N A_{X, 1}=m R N A_{X}(t+h), \quad m R N A_{X, 0}=m R N A_{X}(t), \\
& W_{X, 1}=W_{X}(t+h), \quad W_{X, 0}=W_{X}(t), X_{1}=X(t+h), X_{0} X(t), \\
& \zeta_{X, 1}=\zeta_{X}(t+h), \quad \zeta_{X, 0}=\zeta_{X}(t) .
\end{aligned}
$$

We transform the system (A2):

$$
\left\{\begin{array}{l}
\left(1+h k_{\text {sinm }, X} \psi_{\text {sinm }, X, 0}\right) G_{b u f, X, 1}-h k_{b u f m, X} \psi_{m, X, 0} W_{p, 1}=G_{b u f, X, 0}, \quad X=P, R, M, C, D, \\
\left(1+h k_{d m, X}\right) m R N A_{X, 1}-h k_{s i n m, X} \psi_{s i n m, X, 0} G_{b u f, X, 1}=m R N A_{X, 0}, \quad X=P, R, M, C, D, \\
\left(1+h k_{s i n, X} \psi_{s i n, X, 0}\right) X_{b u f, 1}-h k_{b u f, X} \psi_{X, 0} W_{C, 1}=X_{b u f, 0}, \quad X=P, R, M, C, D, \\
\left(1+h k_{d, X}+h n_{1, X} k_{W X} \zeta_{X, 0}\right) X_{1}-h k_{s i n, X} \psi_{s i n, X, 0} X_{b u f, 1}-h n_{1, X} k_{W X} W_{X, 1}=X, \quad X=P, R, C, M, D, \\
\left(1+h k_{W P}+h k_{d, W_{P}}\right) W_{P, 1}+\sum_{X=P, R, M, C, D} G_{b u f, X, 1}-h k_{W P} \zeta_{P, 0} P_{1}=W_{P, 0}+\sum_{X=P, R, M, C, D} G_{b u f, X, 0}, \\
\left(1+h k_{W C}+h k_{d, W_{C}}\right) W_{C, 1}+2 \sum_{X=P, R, M, C, D} X_{b u f, 1}-h k_{W C} \zeta_{C, 0} C_{1}=W_{C, 0}+2 \sum_{X=P, R, M, C, D} X_{b u f, 0}, \\
\left(1+h k_{W D}+h k_{d, W_{C}}\right) W_{D, 1}-h k_{W D} \zeta_{D, 0} X_{1}=W_{D, 0}, \\
\left(1+h k_{W R}+h \frac{k_{S}}{\rho} \psi_{S, 0}+h k_{d, W_{R}}\right) W_{R, 1}-h k_{W R} \zeta_{R, 0} R_{1}=W_{R, 0} .
\end{array} \Rightarrow\right.
$$




$$
\begin{aligned}
& \int\left(1+h k_{\text {sinm }, X} \psi_{s i n m, X, 0}\right) G_{b u f, X, 1}-h k_{b u f f, X} \psi_{m, X, 0} W_{p, 1}=G_{b u f, X, 0}, \quad X=P, R, M, C, D, \\
& \left(1+h k_{d m, X}\right) m R N A_{X, 1}-h k_{\text {sinm }, X} \psi_{\text {sinm }, X, 0} G_{b u f, X, 1}=m R N A_{X, 0}, \quad X=P, R, M, C, D \text {, } \\
& \left(1+h k_{s i n, X} \psi_{s i n, X, 0}\right) X_{b u f, 1}-h k_{b u f, X} \psi_{X, 0} W_{C, 1}=X_{b u f f, 0}, \quad X=P, R, M, C, D \text {, } \\
& \left(1+h k_{d, X}+h n_{1, X} k_{W X} \zeta_{X, 0}\right) X_{1}-h k_{s i n, X} \Psi_{s i n, X, 0} X_{b u f, 1}-h n_{1, X} k_{W X} W_{X, 1}=X_{0}, \quad X=P, R, M, D, \\
& \left\{\left(1+h k_{d, C}+h n_{1, C} k_{W C} \zeta_{C, 0}\right) C_{1}-h k_{s i n, C} \psi_{s i n, C, 0} \frac{h k_{b u f, C} \psi_{C, 0}}{\left(1+h k_{s i n, C} \psi_{s i n, C, 0}\right)} W_{C, 1}-h n_{1, C} k_{W C} W_{C, 1}=C_{0}+h \frac{k_{s i n, C} \psi_{s i n, C, 0} C_{b u f, 0}}{\left(1+h k_{s i n, C} \psi_{s i n, C, 0}\right)},\right. \\
& \left(1+h k_{W P}+h k_{d, W_{P}}+h \sum_{X=P, R, M, C, D} \frac{k_{\text {bufn }, X} \Psi_{m, X, 0}}{\left(1+h k_{\text {sinm }, X} \psi_{\text {sinm }, X, 0}\right)}\right) W_{P, 1}-h k_{W P} \zeta_{P, 0} P_{1}=W_{P, 0}+h \sum_{X=P, R, M, C, D} \frac{k_{\text {sinm }, X} \psi_{\text {sinm }, X, 0} G_{b u f, X, 0}}{\left(1+h k_{\text {sinm }, X} \psi_{\text {sinm }, X, 0}\right)}, \\
& \left(1+h k_{W C}+h k_{d, W_{C}}+2 h \sum_{X=P, R, M, C, D} \frac{k_{b u f, X} \psi_{X, 0}}{\left(1+h k_{s i n, X} \psi_{s i n, X, 0}\right)}\right) W_{C, 1}-h k_{W C} \zeta_{C, 0} C_{1}=W_{C, 0}+2 h \sum_{X=P, R, M, C, D} \frac{k_{s i n, X} \psi_{s i n, X, 0} X_{b u f, 0}}{\left(1+h k_{s i n, X} \psi_{s i n, X, 0}\right)}, \\
& \left(1+h k_{W D}+h k_{d, W_{C}}\right) W_{D, 1}-h k_{W D} \zeta_{D, 0} X_{1}=W_{D, 0}, \\
& \left(1+h k_{W R}+h \frac{k_{S}}{\rho} \psi_{S, 0}+h k_{d, W_{R}}\right) W_{R, 1}-h k_{W R} \zeta_{R, 0} R_{1}=W_{R, 0} .
\end{aligned}
$$

$$
\begin{aligned}
& \Omega_{m, X, i}=\frac{k_{b u f m, X} \psi_{m, X, i}}{\left(1+h k_{\text {sinm }, X} \psi_{\text {sinm }, X, i}\right)}, \quad \Omega_{m, i}=\sum_{X=P, R, M, C, D} \Omega_{m, X, i}, \\
& \Omega_{X, i}=\frac{k_{b u f, X} \psi_{X, i}}{\left(1+h k_{\text {sin }, X} \psi_{\sin , X, i}\right)}, \quad \Omega_{i}=\sum_{X=P, R, M, C, D} \Omega_{X, i}, \quad X=P, R, C, M, D, \quad i=0,1,
\end{aligned}
$$

We obtain a system for unknowns $C_{1}$ and $W_{C, 1}$ :

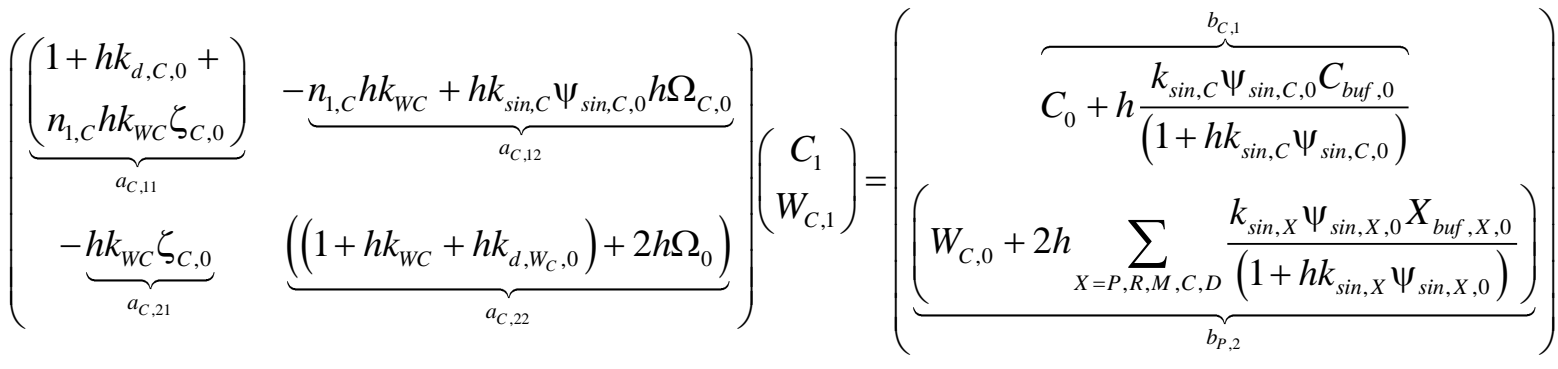

$$
\begin{aligned}
& \operatorname{Det}_{C}=a_{C, 11} a_{C, 22}-a_{C, 12} a_{C, 21}, \operatorname{Det}_{C, 1}=b_{C, 1} a_{C, 22}+b_{C, 2} a_{C, 12}, \operatorname{Det}_{C, 2}=b_{C, 1} a_{C, 21}+b_{C, 2} a_{C, 11} \text {. }
\end{aligned}
$$

From where we find

$$
C_{1}=\frac{\operatorname{Det}_{C, 1}}{\operatorname{Det}_{C}}, \quad W_{C, 1}=\frac{\operatorname{Det}_{C, 2}}{\operatorname{Det}_{C}}
$$

From the equation:

$$
\left(1+h k_{\sin , X} \psi_{\sin , X, 0}\right) X_{b u f, 1}-h k_{b u f, X} \psi_{X, 0} W_{C, 1}=X_{b u f, 0}, \quad X=P, R, M, C, D,
$$

We find:

$$
X_{b u f, 1}=\frac{X_{b u f, 0}+h k_{b u f, X} \psi_{X, 0} W_{C, 1}}{\left(1+h k_{\sin , X} \psi_{\sin , X, 0}\right)}, \quad X=P, R, M, C, D .
$$

The system for $P_{1}$ and $W_{P, 1}$ has the following form: 


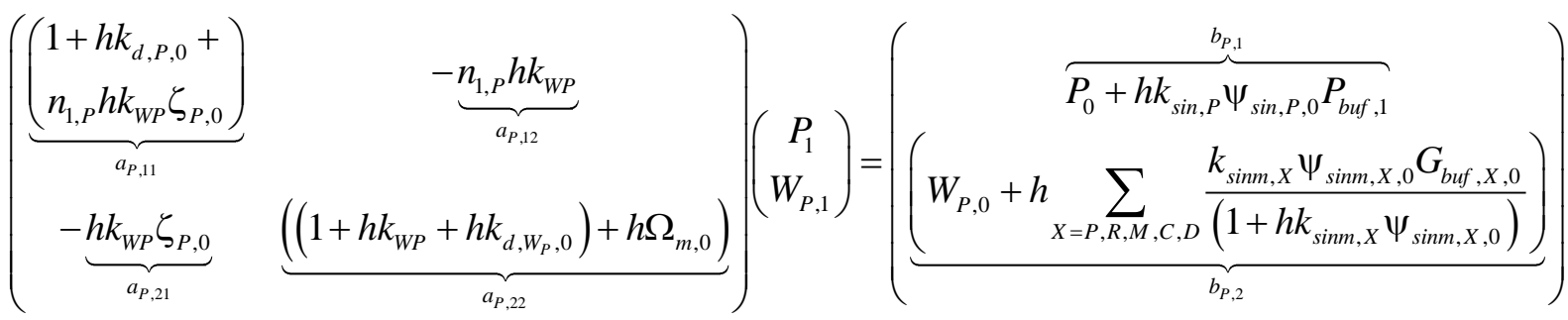

$$
\begin{aligned}
& \operatorname{Det}_{P}=a_{P, 11} a_{P, 22}-a_{P, 12} a_{P, 21}, \operatorname{Det}_{P, 1}=b_{P, 1} a_{P, 22}+b_{P, 2} a_{P, 12}, \operatorname{Det}_{P, 2}=b_{P, 1} a_{P, 21}+b_{P, 2} a_{P, 11} \text {. }
\end{aligned}
$$

From it we find:

$$
P_{1}=\frac{\operatorname{Det}_{P, 1}}{\operatorname{Det}_{P}}, W_{P, 1}=\frac{\operatorname{Det}_{P, 2}}{\operatorname{Det}_{P}}
$$

The system for $P_{1}$ and $W_{P, 1}$ has the following form:

$$
\begin{aligned}
& \left(\begin{array}{c}
\underbrace{\left(\begin{array}{c}
1+h k_{d, R, 0}+ \\
n_{1, R} h k_{W R} \zeta_{R, 0}
\end{array}\right)}_{a_{R, 11}} \\
-\underbrace{h k_{W R} \zeta_{R, 0}}_{a_{R, 21}} \underbrace{\left(1+h k_{S} \frac{S_{0}}{V_{0}}+h k_{W R}+h k_{d, W_{R}, 0}\right)}_{a_{R, 12}\left(n_{1, R} h k_{W R}\right)})
\end{array}\right)\left(\begin{array}{c}
R_{1} \\
W_{R, 1}
\end{array}\right)=\left(\begin{array}{c}
\overbrace{R_{0}+h k_{\text {sin, }} \Psi_{\text {sin }, R, 0} R_{b u f, 1}}^{b_{R, 1}} \\
\frac{W_{R, 0}}{b_{R, 2}}
\end{array}\right), \\
& \operatorname{Det}_{R}=a_{R, 11} a_{R, 22}-a_{R, 12} a_{R, 21}, \operatorname{Det}_{R, 1}=b_{R, 1} a_{R, 22}+b_{R, 2} a_{R, 12}, \operatorname{Det}_{R, 2}=b_{R, 1} a_{R, 21}+b_{R, 2} a_{R, 11} \text {. }
\end{aligned}
$$

From where we find:

From the system

$$
R_{1}=\frac{\operatorname{Det}_{R, 1}}{\operatorname{Det}_{R}}, \quad W_{R, 1}=\frac{\operatorname{Det}_{R, 2}}{\operatorname{Det}_{R}}
$$

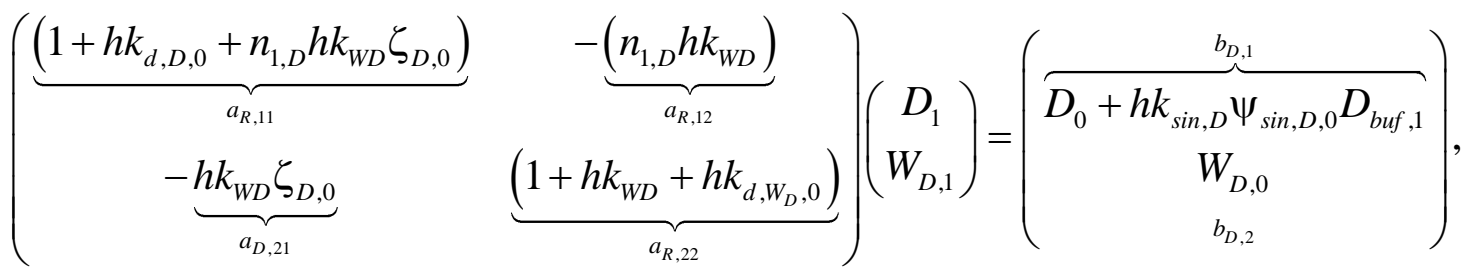

$$
\begin{aligned}
& \operatorname{Det}_{D}=a_{D, 11} a_{D, 22}-a_{D, 12} a_{R, 21}, \operatorname{Det}_{D, 1}=b_{D, 1} a_{D, 22}+b_{D, 2} a_{D, 12}, \operatorname{Det}_{D, 2}=b_{D, 1} a_{D, 21}+b_{D, 2} a_{D, 11} \text {, }
\end{aligned}
$$

We calculate

From

$$
D_{1}=\frac{\operatorname{Det}_{D, 1}}{\operatorname{Det}_{D}}, \quad W_{D, 1}=\frac{\operatorname{Det}_{D, 2}}{D e t_{D}}
$$

$$
\left(1+h k_{\text {sinm }, X} \psi_{\text {sinm }, X, 0}\right) G_{b u f, X, 1}-h k_{b u f m, X} \psi_{m, X, 0} W_{p, 1}=G_{b u f, X, 0}, \quad X=P, R, M, C, D,
$$

We calculate

From

$$
G_{b u f, X, 1}=\frac{G_{b u f, X, 0}+h k_{b u f m, X} \psi_{m, X, 0} W_{P, 1}}{1+h k_{\text {sinm }, X} \psi_{\text {sinm }, X, 0}}, \quad X=P, R, M, C, D
$$

$$
\left(1+h k_{d m, X, 0}\right) M R N A_{X, 1}-h k_{\sin m, X} \psi_{s i n m, X, 0} G_{b u f, X, 1}=M R N A_{X, 0}, \quad X=P, R, M, C, D,
$$


We have

$$
M R N A_{X, 1}=\frac{M R N A_{X, 0}+h k_{\operatorname{sinm}, X} \psi_{\operatorname{sinm}, X, 0} G_{b u f, X, 1}}{1+h k_{d m, X, 0}}, \quad X=P, R, M, C, D .
$$

Collecting everything together, and adding equations with $S, V, Z$, we obtain the final iterative scheme for numerical integration of the system (10) from the text of the article.

$$
\begin{gathered}
C_{1}=\frac{\operatorname{Det}_{C, 1}}{\operatorname{Det}_{C}}, \quad W_{C, 1}=\frac{\operatorname{Det}_{C, 2}}{\operatorname{Det}_{C}}, \\
X_{b u f, 1}=\frac{X_{b u f, 0}+h W_{C, 1} \Omega_{X, 0}}{1+h k_{s i n, X}}, \quad X=P, R, M, C, D, \\
P_{1}=\frac{\operatorname{Det}_{P, 1}}{\operatorname{Det}_{P}}, \quad W_{P, 1}=\frac{\operatorname{Det}_{P, 2}}{\operatorname{Det}_{P}}, \\
R_{1}=\frac{\operatorname{Det}_{R, 1}}{\operatorname{Det}_{R}}, \quad W_{R, 1}=\frac{\operatorname{Det}_{R, 2}}{\operatorname{Det}_{R}}, \\
D_{1}=\frac{\operatorname{Det}_{D, 1}}{\operatorname{Det}_{D}}, \quad W_{D, 1}=\frac{\operatorname{Det}_{D, 2}}{\operatorname{Det}_{D}}, \\
G_{b u f, X, 1}=\frac{G_{b u f, X, 0}+h k_{b u f n, X} \psi_{m, X, 0} W_{P, 1}}{1+h k_{s i n m, X} \psi_{\text {sinm }, X, 0}}, \quad X=P, R, M, C, D, \\
M R N A_{X, 1}=\frac{M R N A_{X, 0}+h k_{s i n m, X} \psi_{\text {sinm }, X, 0} G_{b u f, X, 1}}{1+h k_{d m, X, 0}}, \quad X=P, R, M, C, D, \\
S_{1}=S_{0}\left(1+h \Delta_{S} \frac{k_{S}}{\rho} \psi_{S, 0} W_{R, 1}\right), \quad V_{1}=\rho S_{1}, \quad Z=\frac{Z}{1+h Z_{\text {totl }, u t i l, 0}} .
\end{gathered}
$$




\section{REFERENCES}

1. Ferrell J.E.Jr. Self-perpetuating states in signal transduction: positive feedback, doublenegative feedback and bistability. Curr. Opin. Cell. Biol. 2002. V. 14. P. 140-148.

2. Angeli D., Ferrell J.E. Jr., Sontag E.D. Detection of multistability, bifurcations, and hysteresis in a large class of biological positive-feedback systems. Proc. Natl. Acad. Sci. USA. 2004. V. 101. P. 1822-1827.

3. Ozbudak E.M., Thattai M., Lim H.N., Shraiman B.I., Van Oudenaarden A. Multistability in the lactose utilization network of Escherichia coli. Nature. 2004. V. 427. № 6976. P. 737-740.

4. Smits W.K., Kuipers O.P., Veening J.W. Phenotypic variation in bacteria: the role of feedback regulation. Nat. Rev. Microbiol. 2006. V. 4. № 4. P. 259-271.

5. Dubnau D., Losick R. Bistability in bacteria. Mol. Microbiol. 2006. V. 61. P. 564-572.

6. Piggot P. Epigenetic switching: bacteria hedge bets about staying or moving. Curr. Biol. 2010. V. 20. № 11. P. R480-482.

7. Avendaño M.S., Leidy C., Pedraza J.M. Tuning the range and stability of multiple phenotypic states with coupled positive-negative feedback loops. Nat. Commun. 2013. V. 4. Article No. 2605.

8. Kaern M., Elston T.C., Blake W.J., Collins J.J. Stochasticity in gene expression: from theories to phenotypes. Nat. Rev. Genet. 2005. V. 6. P. 451-464.

9. Sureka K., Ghosh B., Dasgupta A., Basu J., Kundu M., Bose I. Positive feedback and noise activate the stringent response regulator rel in mycobacteria. PLoS One. 2008. V. 3. № 3. Article No. e1771. doi: 10.1371/journal.pone.0001771.

10. To T.L., Maheshri N. Noise can induce bimodality in positive transcriptional feedback loops without bistability. Science. 2010. V. 327. № 5969. P. 1142-1145.

11. Zheng X.D., Yang X.Q., Tao Y. Bistability, probability transition rate and first-passage time in an autoactivating positive-feedback loop. PLoS One. 2011. V. 6. № 3. Article No. e17104. doi: 10.1371/journal.pone.0017104.

12. Shu C.C., Chatterjee A., Dunny G., Hu W.S., Ramkrishna D. Bistability versus bimodal distributions in gene regulatory processes from population balance. PLoS Comput. Biol. 2011. V. 7. № 8. Article No. e1002140.

13. Ghosh S., Banerjee S., Bose I. Emergent bistability: Effects of additive and multiplicative noise. Eur. Phys. J. E Soft. Matter. 2012. V. 35. P. 11. doi: 10.1140/epje/i2012-12011-4.

14. Thomas P., Popović N., Grima R. Phenotypic switching in gene regulatory networks. Proc. Natl. Acad. Sci. USA. 2014. V. 111. №. 19. P. 6994-6999.

15. Casadesús J., Low D.A. Programmed heterogeneity: epigenetic mechanisms in bacteria. J. Biol. Chem. 2013. V. 288. P. 13929-13935.

16. Stewart E.J., Madden R., Paul G., Taddei F. Aging and death in an organism that reproduces by morphologically symmetric division. PLoS Biol. 2005. V. 3. № 2. Article No. e45.

17. Ghosh S., Sureka K., Ghosh B., Bose I., Basu J., Kundu M. Phenotypic heterogeneity in mycobacterial stringent response. BMC Syst. Biol. 2011. V. 5. P. 18.

18. Kotte O., Volkmer B., Radzikowski J.L., Heinemann M. Phenotypic bistability in Escherichia coli's central carbon metabolism. Mol. Syst. Biol. 2014. V. 10. P. 736.

19. Klapper I., Gilbert P., Ayati B.P., Dockery J., Stewart P.S. Senescence can explain microbial persistence. Microbiology. 2007. V. 153. P. 3623-3630.

20. Balaban N.Q., Merrin J., Chait R., Kowalik L., Leibler S. Bacterial persistence as a phenotypic switch. Science. 2004. V. 305. P. 1622-1625.

21. Verstraeten N., Knapen W., Fauvart M., Michiels J. A Historical Perspective on Bacterial Persistence. Methods Mol. Biol. 2016. V. 1333. P. 3-13. 
22. Dörr T., Vulić M., Lewis K. Ciprofloxacin causes persister formation by inducing the TisB toxin in Escherichia coli. PLoS Biol. 2010. V. 8. № 2. Article No. e1000317.

23. Fasani R.A., Savageau M.A. Molecular mechanisms of multiple toxin-antitoxin systems are coordinated to govern the persister phenotype. Proc. Natl. Acad. Sci. USA. 2013. V. 110. P. E2528-E2537.

24. Gelens L., Hill L., Vandervelde A., Danckaert J., Loris R. A general model for toxinantitoxin module dynamics can explain persister cell formation in E. coli. PLoS Comput. Biol. 2013. V. 9. Article No. e1003190.

25. Likhoshvai V.A., Khlebodarova T.M. Coordination of cell growth and DNA replication: a mathematical model. Math. Biol. Bioinf. 2013. V. 8. No. 1. P. 66-92 doi: 10.17537/2013.8.66 (published in Russian)

26. Likhoshvai V.A., Khlebodarova T.M. Mathematical modeling of bacterial cell cycle: The problem of coordinating genome replication with cell growth. J. Bioinform. Comput. Biol. 2014. V. 12. № 3. Article No. 1450009. doi: 10.1142/S0219720014500097.

27. Donachie W.D. Relationship between cell size and time of initiation of DNA replication. Nature. 1968. V. 219. P. 1077-1079.

28. Cooper S., Helmstetter C.E. Chromosome replication and the division cycle of Escherichia coli B/r. J. Mol. Biol. 1968. V. 31. P. 619-644.

29. Escherichia coli and Salmonella typhimurium: Cellular and Molecular Biology. Ed. Neidhardt F.C. Washington D.C.: American Society for Microbiology, 1987. 1654 p.

30. Kennell D., Riezman H. Transcription and translation initiation frequencies of the Escherichia coli lac operon. J. Mol. Biol. 1977. V. 114. P. 1-21.

31. Zaritsky A., Woldringh C.L. Chromosome replication rate and cell shape in Escherichia coli: lack of coupling. J. Bacteriol. 1978. V. 135. № 2. P. 581-587.

32. Pedersen S., Reeh S., Friesen, D.J. Functional mRNA half-lives in E. coli. Mol. Gen. Genet. 1978. V. 166. P. 329-336.

33. Mosteller R.D., Goldstein R.V., Nishimoto K.R. Metabolism of individual proteins in exponentially growing Escherichia coli. J. Biol. Chem. 1980. V. 255. № 6. P. 2524 2532.

34. Selinger D.W., Saxena R.M., Cheung K.J., Church G.M., Rosenow C. Global RNA half-life analysis in Escherichia coli reveals positional patterns of transcript degradation. Genome Res. 2003. V. 13. № 2. P. 216-223.

35. Bernstein J.A., Lin P.H., Cohen S.N., Lin-Chao S. Global analysis of Escherichia coli RNA degradosome function using DNA microarrays. Proc. Natl. Acad. Sci. USA. 2004. V. 101. № 9. P. 2758-2763.

36. Jayapal K.P., Sui S., Philp R.J., Kok Y.J., Yap M.G., Griffin T.J., Hu W.S. Multitagging proteomic strategy to estimate protein turnover rates in dynamic systems. J. Proteome Res. 2010. V. 9. № 5. P. 2087-2097.

37. Taniguchi Y., Choi P.J., Li G.W., Chen H., Babu M., Hearn J., Emili A., Xie X.S. Quantifying E. coli proteome and transcriptome with single-molecule sensitivity in single cells. Science. 2010. V. 329. № 5991. P. 533-538.

38. Inouye M., Shaw J., Shen C. The assembly of a structural lipoprotein in the envelope of Escherichia coli. J. Biol. Chem. 1972. V. 247. № 24. P. 8154-8159.

39. Schaechter M., Maaloe O., Kjeldgaard N.O. Dependency on medium and temperature of cell size and chemical composition during balanced grown of Salmonella typhimurium. J. Gen. Microbiol. 1958. V. 19. P. 592-606.

40. Schaechter M., Williamson J.P., Hood J.R. Jr., Koch A.L. Growth, cell and nuclear divisions in some bacteria. J. Gen. Microbiol. 1962. V. 29. P. 421-434. 
41. Yoshikawa H., O'Sullivan A., Sueoka N. Sequential replication of the Bacillus subtilis chromosome. III. Regulation of initiation. Proc. Natl. Acad. Sci. USA. 1964. V. 52. P. 973-980.

42. Zaritsky A., Vischer N., Rabinovitch A. Changes of initiation mass and cell dimensions by the 'eclipse'. Mol. Microbiol. 2007. V. 63. P. 15-21.

43. Zaritsky A., Wang P., Vischer N.O. Instructive simulation of the bacterial cell division cycle. Microbiology. 2011. V. 157. P. 1876-1885.

44. Grant M.A., Saggioro C., Ferrari U., Bassetti B., Sclavi B., Lagomarsino M.C. DnaA and the timing of chromosome replication in Escherichia coli as a function of growth rate. BMC Syst. Biol. 2011. V. 5. Article No. 201.

45. Soo V.W., Cheng H.Y., Kwan B.W., Wood T.K. De novo synthesis of a bacterial toxin/antitoxin system. Sci. Rep. 2014. V. 4. Article No. 4807.

46. Keren I., Shah D., Spoering A., Kaldalu N., Lewis K. Specialized persister cells and the mechanism of multidrug tolerance in Escherichia coli. J. Bacteriol. 2004. V. 186. P. 8172-8180.

47. Shah D., Zhang Z., Khodursky A., Kaldalu N., Kurg K., Lewis K. Persisters: a distinct physiological state of E. coli. BMC Microbiol. 2006. V. 6. Article No. 53. 